\title{
Differential Immuno-Reactivity to Genomic DNA, RNA and Mitochondrial DNA is Associated with Auto-Immunity
}

\author{
Vilena V. Ivanova ${ }^{a}$ Svetlana F. Khaiboullina ${ }^{a, b}$ Ekaterina E. Cherenkova ${ }^{a}$ \\ Ekaterina V. Martynova ${ }^{a}$ Tatiana A. Nevzorova ${ }^{a}$ Michail A. Kunst ${ }^{c}$ \\ Timur B. Sibgatullin ${ }^{c}$ Adelia N. Maksudovac Paulo J. Oliveira ${ }^{d}$ \\ Vincent C. Lombardia,b András Palotás ${ }^{a, e}$ Albert A. Rizvanov ${ }^{a}$ \\ aKazan Federal University, Kazan, Russia; bUniversity of Nevada, Reno, NV, USA; 'Kazan State Medical \\ University, Kazan, Russia; 'Center for Neuroscience and Cell Biology, University of Coimbra, Coimbra, \\ Portugal; ' Asklepios-Med (Private Medical Practice and Research Center), Szeged, Hungary
}

\section{Key Words}

Auto-antibody • Auto-antigens - Auto-immune disease $\cdot$ Biomarker $•$ Mitochondria $•$ Nucleic acid $\bullet$ Systemic lupus erythematosus (SLE)

\begin{abstract}
Background: Circulating auto-reactive antibodies are hallmark features of auto-immune diseases, however little is known with respect to the specificity of such bio-markers. In the present study, we investigated the specificity of anti-nucleic acid antibodies in the blood of subjects with systemic lupus erythematosus (SLE) and healthy controls. Methods: Sera from 12 SLE cases and 8 controls were evaluated for immuno-reactivity to purified RNA, DNA and mitochondrial DNA (mtDNA) by enzyme-linked immuno-sorbent assay (ELISA). Results: As expected, immuno-reactivity to total nucleic acids was significantly higher in subjects with SLE when compared to healthy controls, however a clear distinction was observed among the various nucleic acid sub-types, with sera from SLE subjects displaying the greatest immunoreactivity to RNA followed by mtDNA and then total DNA. Conclusion: The identification of auto-reactive antibodies can serve as highly sensitive biomarkers, although their specificity may not always allow diagnostic certainty. The knowledge that auto-antibodies in subjects with SLE display differential immuno-reactivity may help to improve existing diagnostics and may lead to a better understanding of the pathogenesis of auto-immune disorders.
\end{abstract}




\section{Introduction}

Systemic lupus erythematosus (SLE) is an auto-immune disease characterized by a plethora of clinical presentation and cycles of reactivation and remission. The disease is often diagnosed between the ages of 15 to 35, with substantially more women being afflicted (male/female ratio is 9:1) [1]. Although genetic and environmental factors are believed to play an important role in its pathogenesis, identifying specific disease triggers remains elusive, hampering further development of specific therapy.

Circulating anti-dsDNA antibodies are hallmark features of SLE [2]. These antibodies are considered to be pathogenic and represent high-avidity IgG isotypes reacting specifically with dsDNA $[3,4]$. Consistently detected in the serum, anti-dsDNA antibodies become a reliable marker for SLE diagnosis and are used as key criterion for disease classification $[5,6]$. Persistent circulation of anti-dsDNA antibodies suggests that autoimmunity to nucleic acid containing molecules is essential for SLE pathogenesis. In addition to dsDNA, histones, ribonucleo-proteins and dsRNA have been shown to be targets for immune response in SLE [6-8]. Recently, potential immunogenicity of peroxy-nitrite modified mitochondrial DNA (mtDNA) has been shown in SLE [9]. Additionally, increased serum level of mtDNA was detected in patients diagnosed with various neurodegenerative disorders, such as autism, Parkinson disease and multiple sclerosis [10-12]. Several authors have suggested that mtDNA can act as trigger points for the development of autoimmune disorders as well $[10,13]$. Although immune reactivity towards nucleic acids is well established, it remains to determine which type of nucleic acids are more immunogenic in SLE.

There are two sources of nucleic acid auto-antigens in SLE: apoptosis and NETosis [14, 15]. Increased apoptosis of $\mathrm{T}$ lymphocytes, neutrophils, monocytes and macrophages has been documented in SLE cases [16-18]. Recently, NETosis has been described in association with pediatric SLE [19]. Normally, genetic material released during apoptosis and NETosis is rapidly and effectively cleared by phagocytosis [20]. Swift clearance of apoptotic material is important to maintain immune tolerance to self-antigens. However, during SLE, clearance of genetic material is delayed leading to subsequent accumulation of apoptotic cell debris, which can provoke inflammatory response and breakdown of self-tolerance $[21,22]$. Impaired clearance of neutrophil extracellular traps (NETs) has been described in SLE cases as well [23]. It has been suggested that reduced degradation of NETs is associated with decreased DNAse I activity which is often observed in SLE [24]. Taken together, massive release of genetic material in combination with its slow clearance facilitates inflammation and can potentially breach self-tolerance.

Many nuclear auto-antigens associated with SLE are found within apoptotic blebs [2527]. Importantly, apoptotic blebs contain modified DNA and RNA molecules, which can be recognized as foreign by immune effector cells and trigger inflammatory reactions. Although all types of nucleic acids could be potential auto-antigens in SLE, little is known regarding the different immunoreactivities of antibodies to genomic DNA, mtDNA and RNA molecules in this disease. Here we present data on serum antibody immunoreactivity to various nucleic acids in SLE subjects. Our data suggest that sera from subjects with SLE have the highest reactivity to RNA followed by mtDNA and then total DNA. Further studies will be required to reveal clinical significance of this differential immunoreactivity.

\section{Materials and Methods}

\section{SLE sera samples}

Twelve subjects who were admitted to the Kazan Medical Academy, Republic of Tatarstan, were enrolled into this study. Diagnosis of SLE was established based on clinical presentation and presence of anti-nuclear antibodies (ANA). Sera from 8 healthy individuals were collected and served as our controls. All sera were heat inactivated $\left(56^{\circ} \mathrm{C} ; 50 \mathrm{~min}\right)$. The Institutional Review Board of the Kazan Federal University approved this study and informed consent was obtained from each study subject according to the guidelines 
Table 1. Sequences of primers for PCR amplification

\begin{tabular}{ll}
\hline Primer name & Nucleotide sequence $5^{\prime} \rightarrow 3^{\prime}$ \\
\hline 18S-SR1R(1F) & TACCTGGTTGATQCTGCCAGT \\
18S- SR1(578R) & ATTACCGCGGCTGCT \\
COI (Human1F) & GGTCAACAAATCATAAAGATATTGG \\
COI (Human1R) & TAAACTTCAGGGTGACCAAAAAATCA \\
\hline
\end{tabular}

approved under this protocol (article 20, Federal Law "Protection of Health Right of Citizens of Russian Federation" N323- FZ, 11.21.2011).

Extraction of nucleic acids

Total DNA and RNA were isolated from HEK cells using Quick-gDNAMiniPrep and Quick-RNA ${ }^{\text {TM }}$ MidiPrep kits, respectively, according to manufacturer's instructions (ThermoFisher Scientific). RNA samples were treated with DNAse I (ThermoFisher Scientific) to eliminate potential DNA contamination and mtDNA was isolated using the Quick-gDNAMiniPrep kit (ThermoFisher Scientific) according to manufacturer's instructions. Briefly, HEK cells were resuspended in isolation buffer $(0.3 \mathrm{M}$ mannitol, $0.1 \%$ BSA, $0.2 \mathrm{mM}$ EDTA, 10mM HEPES, 1X protease inhibitor cocktail; pH 7.4) and homogenized for $1 \mathrm{~min}$. Cytosolic and nuclear fractions were then separated by centrifugation $\left(1000 \mathrm{~g}\right.$ at $\left.4{ }^{\circ} \mathrm{C} ; 10 \mathrm{~min}\right)$ and supernatants were further centrifuged to pellet the mitochondrial fraction $\left(14,000 \mathrm{~g}\right.$ for $20 \mathrm{~min}$ at $4{ }^{\circ} \mathrm{C}$ ) The pellet was then extracted using the Quick-DNA ${ }^{\mathrm{Tm}}$ MiniPrep kit (ThermoFisher Scientific), to yield enriched mtDNA.

\section{Enzyme-linked immuno-sorbent assay (ELISA)}

Serum immunoreactivity to nucleic acids was determined using a modified ELISA method. Briefly, polystyrene plates were ultraviolet (UV) irradiated for 2 hours before use. Plates were coated with total RNA, DNA and mtDNA ( $1 \mu \mathrm{g} /$ well; citrate buffer ( $0.2 \mathrm{M}$ citric acid, $0.1 \mathrm{M}$ sodium hydrophosphate, $\mathrm{pH}$ 5.0) and incubated overnight at $37^{\circ} \mathrm{C}$. At the end of the incubation, the plates were washed (3x) using phosphatebuffered saline (PBST; $0.1 \%$ tween 20 ) and blocked (5\% BSA in PBS) for 2 hours at $37^{\circ} \mathrm{C}$. The plates were again washed (3x), and incubated with $100 \mu \mathrm{l}$ of heat-inactivated serum $\left(56^{\circ} \mathrm{C} ; 50 \mathrm{~min}\right)$ for $90 \mathrm{~min}$ at $37^{\circ} \mathrm{C}$ followed by incubation at $4^{\circ} \mathrm{C}$ for $30 \mathrm{~min}$. The plates were again washed (3x), and incubated with HRPconjugated goat anti-human IgG antibodies $\left(100 \mu \mathrm{l} /\right.$ well; 1:25000) for 1 hour at $37^{\circ} \mathrm{C}$. The plates were developed using TMB peroxidase substrate and the optical density (OD) was measured at $450 \mathrm{~nm}$. Each experiment was repeated four times.

Polymerase chain reaction (PCR) analysis

Aliquots (50 ng) of DNA extract were used for all PCR analyses. The presence of mtDNA in the template was confirmed by amplification of PCR products using primers for human cytochrome oxidase subunit I (COI) [28]. Also, primers for the gene coding for 18S rRNA were used to detect presence of genomic DNA. Primer sequences are summarized in Table 1. Each PCR reaction mixture (30 $\mu \mathrm{l})$ consisted of $1 \mathrm{x}$ PCR buffer, $1 \mathrm{mmol} / \mathrm{l} \mathrm{MgCl}, 200 \mathrm{mmol} / \mathrm{l}$ of each deoxynucleotide triphosphate, $2.5 \mathrm{U}$ Taq DNA polymerase and $100 \mathrm{ng}$ of each amplification primer. All PCR reagents were purchased from Applied Biosystems, (Carlsbad, CA). Amplification products were separated in $1 \%$ agarose gels containing ethidium bromide and confirmed by sequencing.

Statistical analyses

Data are presented as Mean \pm SE. Statistical analyses were performed using Mann-Whitney p-test for comparisons between individual experimental groups. Significance was established at a value of $p \leq 0.01$.

\section{Results}

Quality analysis of genomic DNA, mtDNA and RNA extracts from HEK cells

In order to confirm the integrity and quality of nucleic acid preparations, samples from three preparation methods were analyzed by gel electrophoresis (Fig. 1). High molecular weight products, representing total DNA, were prepared using the Quick-gDNAMiniPrep kit (Fig. 1A). Two bands corresponding to $18 \mathrm{~S}$ and 28S RNA were observed for samples 
Fig. 1. Quality analysis of nucleic acid extracts. Total DNA, total RNA and mtDNA were separated using $1 \%$ agarose gel. Nucleic acids were visualized using ethidium bromide. A - genomic DNA, B - total RNA, C - mitochondrial DNA. 1 - DNA ladder, 2 - nucleic acids.

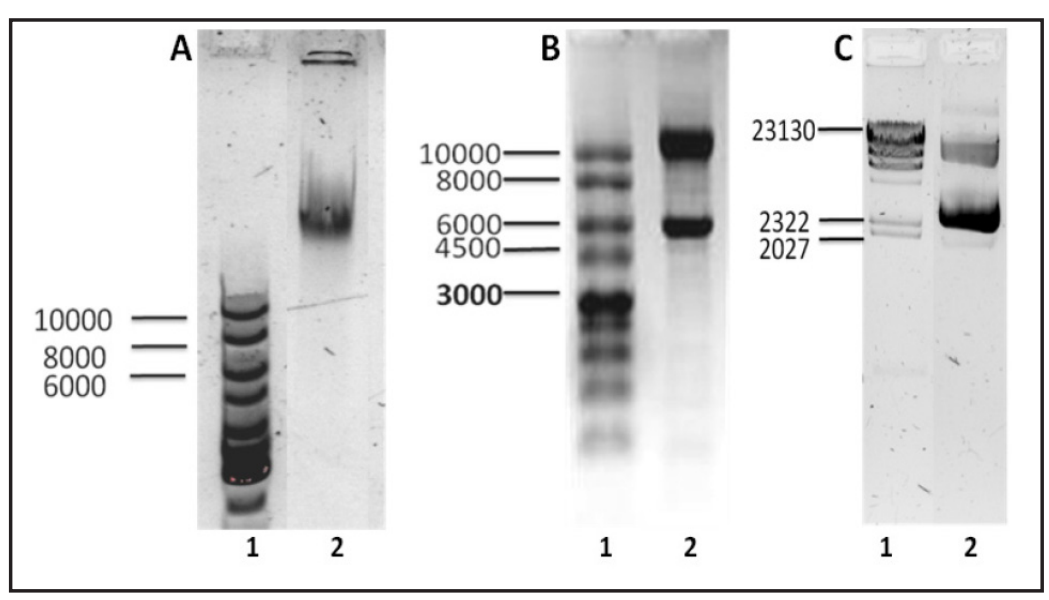

Fig. 2. Qualitative analysis of nucleic acid extracts using PCR. Expected PCR products: gene coding for $18 \mathrm{~S}$ rRNA - $500 \mathrm{bp}$; gene coding for COI - $1542 \mathrm{bp}$. Lines 1 and 2 - mt DNA template; lines 3 and 4 - total DNA template.

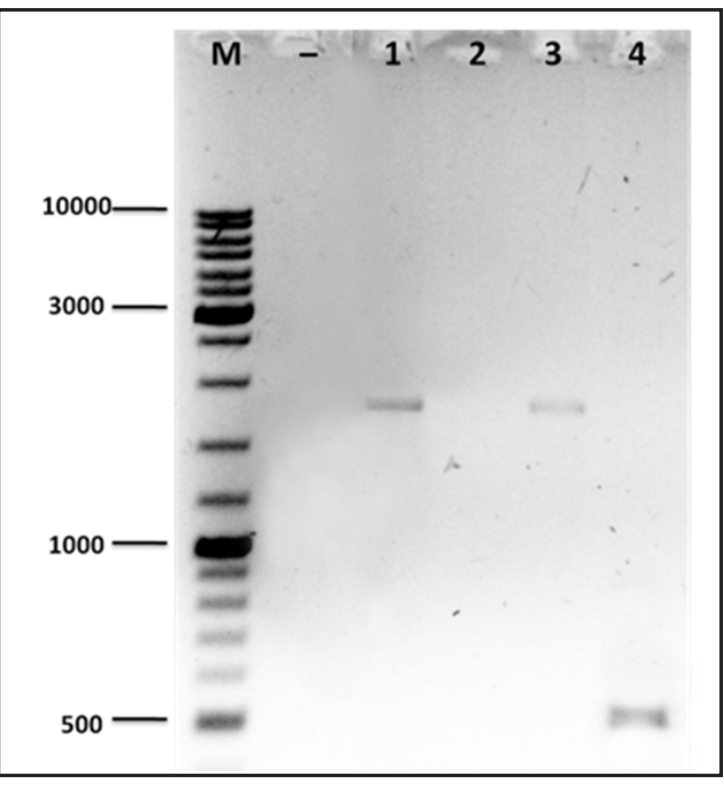

prepared using the Quick-RNA ${ }^{\mathrm{TM}}$ MidiPrep kit (Fig. 1B). Finally, bands $\mathrm{t}$ and b, representing intact mtDNA, were observed upon analysis of the differential centrifugation preparation (Fig. 1C). Electrophoretic analysis confirmed the identity and the integrity of each respective nucleic acid preparation.

In order for confirm the purity of the mtDNA preparation; we utilized PCR analysis to determine the presence or absence of genomic nucleic acid (Fig. 2). When mtDNA used as the PCR template, a band consistent with a COI amplification product was observed, and confirmed by sequencing (Fig. 2, line 1). However, an amplification product for DNA coding for rRNA was absent, thus confirming the absence of contaminating genomic DNA (Fig. 2, line 2). Furthermore, when total DNA was used as the template, a PCR product was detected for rRNA confirming presence of genomic DNA (Fig. 2, line 4). As expected, mtDNA was present in the total DNA extract, as confirmed by amplification product using the COI primers (Fig. 2 , line 3). Therefore, we concluded that although some mtDNA contamination was present in the total DNA extract, there was no genomic DNA contamination present in the mtDNA preparations.

\section{ELISA analyses of sera immunoreactivity to various nucleic acids}

Immunoreactivity of sera to different nucleic acids preparations was analyzed by ELISA for SLE cases and healthy donors. Healthy donor sera revealed low immunoreactivity to all nucleic acid preparations tested (Fig. 3). Immunoreactivity of sera from SLE cases to mtDNA 
Fig. 3. Immuno-reactivity of serum from SLE cases and healthy donors to mtDNA, total RNA and total DNA. A. Affinity of serum samples to various nucleic acids was analyzed using ELISA method. Total DNA, total RNA and mtDNA were isolated from HEK cells and used as target antigen. dark gray bar - healthy donor's serum $(n=8)$; light gray bars - SLE serum $(n=12)$; 1 - mtDNA; 2 - total RNA; 3 - total DNA. B. Affinity value of serum antibodies of SLE patients and healthy donors to investigated nucleic acids (NA) by ELISA test. $\left({ }^{*}\right)$ - significance different between SLE patients and healthy donors, $\mathrm{p} \leq 0.01$. Mann - Whitney U-test was used.

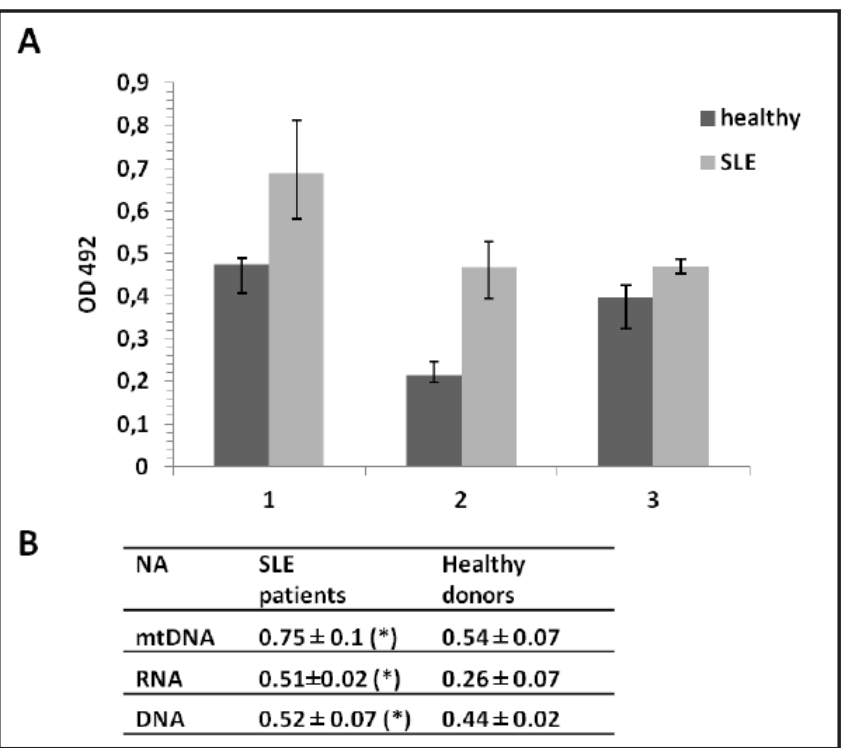

Fig 4. The ratio between the OD values of SLE patients and healthy donors. $\left(^{*}\right)$ - significantly different between SLE patients and healthy donors, $\mathrm{p} \leq 0.01$. 1 : total DNA, 2: total RNA, 3: mtDNA.

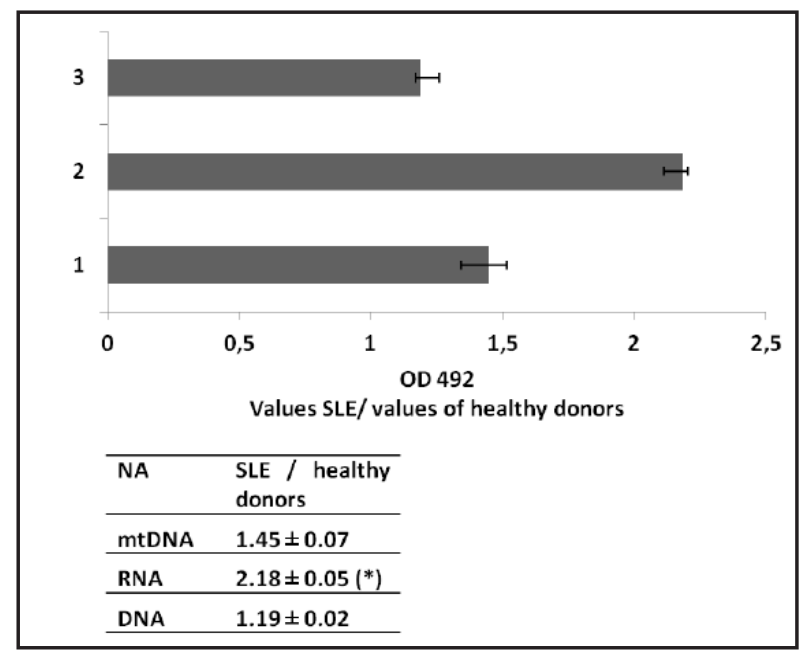

Table 2. Reactivity of sera from SLE cases (12) and controls (8) to respective nucleic acids

\begin{tabular}{lllll}
\hline NA & \multicolumn{2}{l}{ SLE patients } & \multicolumn{2}{c}{ Healthy donors } \\
\hline mtDNA & $10 / 12$ & $83 \%$ & $5 / 8$ & $62.5 \%$ \\
RNA & $8 / 12$ & $66.7 \%$ & $4 / 8$ & $50 \%$ \\
DNA & $7 / 12$ & $58.3 \%$ & $4 / 8$ & $50 \%$ \\
With all & $7 / 12$ & $58.3 \%$ & $1 / 8$ & $12.5 \%$ \\
\hline
\end{tabular}

and RNA was significantly higher when compared to that in healthy controls. Interestingly, immunoreactivity of SLE sera to RNA was more than 2-fold higher than that of healthy controls ( $0.51 \pm 0.02$ vs $0.26 \pm 0.07$, respectively). Although the immunoreactivity of SLE sera to total DNA differed significantly as compared to healthy controls (Fig. 3), the overall values, on average, differed only by 1.18 -fold ( $0.52 \pm 0.07$ vs $0.44 \pm 0.02)$ between SLE and the healthy control group.

Overall, a greater number of sera from SLE subjects showed immunoreactivity with nucleic acids as compared to sera from healthy subjects. For example, seven SLE cases (58.3\%) displayed immunoreactivity to all nucleic acid preparations used in this study (Table 2). In contrast, only one serum sample (12.5\%) from a healthy donor reacted with all 
nucleic acid preparations (Table 2). However, when sera were analyzed for reactivity to each individual type of nucleic acid preparation, more SLE sera samples were found to react with mtDNA (83\%) as compared to healthy controls (62.5\%). However, number of sera samples from SLE and healthy control reacting with total DNA and RNA was compatible $(58.3 \%$ vs $50 \%$ and 66.7 vs $50 \%$, respectively) (Table 2 ). Therefore, we conclude that the anti-nucleic acid antibody pool in SLE sera is more heterogeneous as compared to that in healthy donors. SLE serum has higher immunoreactivity to mtDNA. Also, frequency of anti-mtDNA antibody is higher in SLE cases than in healthy controls.

\section{Discussion}

In this report, we have shown that sera from SLE cases are immunoreactive to RNA, mtDNA and total DNA. Additionally, we have shown that the observed immunoreactivity is hierarchic in nature with the highest immunoreactivity observed to RNA, followed by mtDNA and then total DNA. Although significantly different between cases and controls, mean values for total DNA immunoreactivity were not striking. The presence of serum antiRNA and anti-DNA antibodies characterize SLE $[8,29,30]$. It is believed that an increased rate of apoptosis results in a massive release of enzymatically modified nucleic acids in SLE. Subsequently, these modified nucleic acids are recognized as "foreign" by immune effector cells, thus triggering immune response $[9,31,32]$. Previous studies have reported that these DNA fragments have unusually high GC and dinucleotide CpG content [33-35], consistent with the immune complexes isolated from the sera of SLE cases [36]. Other studies have reported that sera from SLE cases are immunoreactive to $C p G$ and $C+G$ rich DNA fragments $[34,36]$. Furtheremore, it has been shown that in addition to a high CpG content, low level of methylation is a distinctive feature of DNA fragments detected in SLE sera [37]. Taken together, these data suggest that DNA fragments in the sera of SLE cases can be characterized by high $\mathrm{CpG}$ content and hypomethylation.

It is believed that the high levels of circulating DNA associated with SLE are the result of increased apoptosis [36], however, key features of DNA fragments are not consistent with genomic origin. Therefore, the exact origin of these DNA fragments remains obscure. Our data suggest that the sera from SLE cases are immunoreactive to mtDNA to a greater extent than total DNA. Interestingly, the physical characteristics of mtDNA closely resemble those described for DNA fragments found in SLE serum. For example, a distinct physical characteristic of mtDNA is a low level of methylation. In fact, Hong et al. reported that CpG methylation is not observed in mtDNA at a biologically meaningful level [38]. Although the difference is small, the CG content of mitochondrial DNA is higher than that of genomic DNA ( $44 \%$ vs $42 \%$, respectively). We suggest that mtDNA may play role in pathogenesis of SLE, serving as an antigen for humoral immune activation and subsequent formation of immune complexes. In support to this assumption, Collins et al. demonstrated that intra-articular injection of mtDNA induced arthritis in an animal model [39]. In contrast, an inflammatory reaction was absent when the animals were injected with genomic DNA. Furthermore, the authors demonstrated that low-level methylation of mtDNA is essential for activation of inflammation [39]. In conclusion, the authors suggested that mtDNA might play a role in pathogenesis of arthritis, since it has been detected in the synovial fluid of subjects with rheumatoid arthritis but not of control subjects. In that mtDNA displays inflammatogenic properties and activates leukocytes to produce proinflammatory cytokines, we suggest that mtDNA might play a role in the initiation of inflammation as well as formation of pathognomonic immune complexes in SLE cases.

Over expression of type I interferon is a hallmark of SLE [40, 41]. Plasmacytoid dendritic cells (pDC) are the principal producers of type I interferon (IFN) [42]. Expression of IFN $\alpha$ is initiated through engagement of toll-like receptors (TLR) 7 and 9 when stimulated with single stranded RNA and non-methylated CpG DNA, respectively [43-45]. Recently, the presence of immunostimulatory motifs on mtDNA has been reported by Reis et al. [46]. The authors 
demonstrated that mtDNA fragments can be spontaneously taken up by pDCs and processed through the TLR9 associated endosomal maturation pathway [46]. Furthermore, mtDNA, especially its unmethylated CpG islands, exhibited strong immunostimulatory activity and IFN $\alpha$ production. Therefore, we propose that mtDNA may play role in activation of pDCs and increased production of IFN $\alpha$.

\section{Conclusions}

Our data demonstrate that the sera from SLE cases display a greater immunoreactivity to total RNA and DNA when compared to healthy controls. Additionally, significantly higher levels of immunoreactivity to mtDNA were observed for the sera of SLE cases when compared to healthy controls. Finally, the sera from more than half of all SLE cases $(58.3 \%)$ demonstrated immunoreactivity to all types of nucleic acid preparations as compared to only one serum sample $(12.5 \%)$ from a healthy donor. In that a greater number of SLE cases displayed immunoreactivity to mtDNA when compared to healthy controls, we conclude that mtDNA may play role in pathogenesis of SLE. This assumption is corroborated by the recent report of pDC activation by mtDNA leading to the production of IFN $\alpha$.

\section{Acknowledgement}

The work is performed according to the Russian Government Program of Competitive Growth of Kazan Federal University and funded by the subsidy allocated to Kazan Federal University for the state assignment in the sphere of scientific activities. Some of the experiments were conducted with support of Interdisciplinary Center of Collective Use and Pharmaceutical Research and Education Center, Kazan (Volga Region) Federal University, Kazan, Russia.

\section{References}

1 Soto ME, Vallejo M, Guillen F, Simon JA, Arena E, Reyes PA: Gender impact in systemic lupus erythematosus. Clin Exp Rheumatol 2004;22:713-721.

$\checkmark 2$ Haugbro K, Nossent JC, Winkler T, Figenschau Y, Rekvig OP: Anti-dsdna antibodies and disease classification in antinuclear antibody positive patients: the role of analytical diversity. Ann Rheum Dis 2004;63:386-394.

-3 Lopez-Hoyos M, Cabeza R, Martinez-Taboada VM, Crespo J, SanSegundo D, Blanco R, Lopez-Escribano H, Pena M, Rodriguez-Valverde V: Clinical disease activity and titers of anti-dsdna antibodies measured by an automated immunofluorescence assay in patients with systemic lupus erythematosus. Lupus 2005;14:505509.

4 Winfield JB, Faiferman I, Koffler D: Avidity of anti-DNA antibodies in serum and igg glomerular eluates from patients with systemic lupus erythematosus. Association of high avidity antinative DNA antibody with glomerulonephritis. J Clin Invest 1977;59:90-96.

5 Hochberg MC: Updating the american college of rheumatology revised criteria for the classification of systemic lupus erythematosus. Arthritis Rheum 1997;40:1725.

6 Gualtierotti R, Biggioggero M, Penatti AE, Meroni PL: Updating on the pathogenesis of systemic lupus erythematosus. Autoimmun Rev 2010;10:3-7.

7 Ippolito A, Wallace DJ, Gladman D, Fortin PR, Urowitz M, Werth V, Costner M, Gordon C, Alarcon GS, Ramsey-Goldman R, Maddison P, Clarke A, Bernatsky S, Manzi S, Bae SC, Merrill JT, Ginzler E, Hanly JG, Nived O, Sturfelt G, Sanchez-Guerrero J, Bruce I, Aranow C, Isenberg D, Zoma A, Magder LS, Buyon J, Kalunian K, Dooley MA, Steinsson K, van Vollenhoven RF, Stoll T, Weisman M, Petri M: Autoantibodies in systemic lupus erythematosus: Comparison of historical and current assessment of seropositivity. Lupus 2011;20:250-255. 
8 Schur PH, Monroe M: Antibodies to ribonucleic acid in systemic lupus erythematosus. Proc Natl Acad Sci USA 1969;63:1108-1112.

-9 Al-Shobaili HA, Rasheed Z: Physicochemical and immunological studies on mitochondrial DNA modified by peroxynitrite: Implications of neo-epitopes of mitochondrial DNA in the etiopathogenesis of systemic lupus erythematosus. Lupus 2013;22:1024-1037.

10 Vyshkina T, Sylvester A, Sadiq S, Bonilla E, Canter JA, Perl A, Kalman B: Association of common mitochondrial DNA variants with multiple sclerosis and systemic lupus erythematosus. Clin Immunol 2008;129:31-35.

11 Shiraishi W, Hayashi S, Kamada T, Isobe N, Yamasaki R, Murai H, Ohyagi Y, Kira J: A case of neuromyelitis optica harboring both anti-aquaporin-4 antibodies and a pathogenic mitochondrial DNA mutation for Leber's hereditary optic neuropathy. Mult Scler 2014;20:258-260.

12 Zhang B, Angelidou A, Alysandratos KD, Vasiadi M, Francis K, Asadi S, Theoharides A, Sideri K, Lykouras L, Kalogeromitros D, Theoharides TC: Mitochondrial DNA and anti-mitochondrial antibodies in serum of autistic children. J Neuroinflamm 2010;7:80.

13 Quaio CR, Carvalho JF, da Silva CA, Bueno C, Brasil AS, Pereira AC, Jorge AA, Malaquias AC, Kim CA, Bertola DR: Autoimmune disease and multiple autoantibodies in 42 patients with rasopathies. Am J Med Genet A 2012;158A:1077-1082.

14 Knight JS, Carmona-Rivera C, Kaplan MJ: Proteins derived from neutrophil extracellular traps may serve as self-antigens and mediate organ damage in autoimmune diseases. Front Immunol 2012;3:380.

15 Munoz LE, van Bavel C, Franz S, Berden J, Herrmann M, van der Vlag J: Apoptosis in the pathogenesis of systemic lupus erythematosus. Lupus 2008;17:371-375.

-16 Bijl M, Reefman E, Horst G, Limburg PC, Kallenberg CG: Reduced uptake of apoptotic cells by macrophages in systemic lupus erythematosus: Correlates with decreased serum levels of complement. Ann Rheum Dis 2006;65:57-63.

17 Ren Y, Tang J, Mok MY, Chan AW, Wu A, Lau CS: Increased apoptotic neutrophils and macrophages and impaired macrophage phagocytic clearance of apoptotic neutrophils in systemic lupus erythematosus. Arthritis Rheum 2003;48:2888-2897.

18 Shoshan Y, Shapira I, Toubi E, Frolkis I, Yaron M, Mevorach D: Accelerated fas-mediated apoptosis of monocytes and maturing macrophages from patients with systemic lupus erythematosus: Relevance to in vitro impairment of interaction with ic3b-opsonized apoptotic cells. J Immunol 2001;167:5963-5969.

19 Garcia-Romo GS, Caielli S, Vega B, Connolly J, Allantaz F, Xu Z, Punaro M, Baisch J, Guiducci C, Coffman RL, Barrat FJ, Banchereau J, Pascual V: Netting neutrophils are major inducers of type i ifn production in pediatric systemic lupus erythematosus. Sci Transl Med 2011;3:73ra20.

20 Savill J: Recognition and phagocytosis of cells undergoing apoptosis. Brit Med Bull 1997;53:491-508.

21 Cohen PL, Caricchio R, Abraham V, Camenisch TD, Jennette JC, Roubey RA, Earp HS, Matsushima G, Reap EA: Delayed apoptotic cell clearance and lupus-like autoimmunity in mice lacking the c-mer membrane tyrosine kinase. J Exp Med 2002;196:135-140.

-22 Dieker JW, van der Vlag J, Berden JH: Triggers for anti-chromatin autoantibody production in SLE. Lupus 2002;11:856-864.

23 Cairns AP, Crockard AD, McConnell JR, Courtney PA, Bell AL: Reduced expression of cd44 on monocytes and neutrophils in systemic lupus erythematosus: Relations with apoptotic neutrophils and disease activity. Ann Rheum Dis 2001;60:950-955.

24 Skiljevic D, Jeremic I, Nikolic M, Andrejevic S, Sefik-Bukilica M, Stojimirovic B, Bonaci-Nikolic B: Serum dnase i activity in systemic lupus erythematosus: Correlation with immunoserological markers, the disease activity and organ involvement. Clin Chem Lab Med 2013;51:1083-1091.

25 Casciola-Rosen L, Rosen A, Petri M, Schlissel M: Surface blebs on apoptotic cells are sites of enhanced procoagulant activity: Implications for coagulation events and antigenic spread in systemic lupus erythematosus. Proc Natl Acad Sci USA 1996;93:1624-1629.

-26 Casciola-Rosen LA, Anhalt G, Rosen A: Autoantigens targeted in systemic lupus erythematosus are clustered in two populations of surface structures on apoptotic keratinocytes. J Exp Med 1994;179:13171330.

27 Mucke L, Abraham CR, Ruppe MD, Rockenstein EM, Toggas SM, Mallory M, Alford M, Masliah E: Protection against HIV-1 gp120-induced brain damage by neuronal expression of human amyloid precursor protein. J Exp Med 1995;181:1551-1556. 
28 Anderson S, Bankier AT, Barrell BG, de Bruijn MH, Coulson AR, Drouin J, Eperon IC, Nierlich DP, Roe BA, Sanger F, Schreier PH, Smith AJ, Staden R, Young IG: Sequence and organization of the human mitochondrial genome. Nature 1981;290:457-465.

29 Alarcon-Segovia D, Fishbein E: Immunochemical characterization of the anti-rna antibodies found in scleroderma and systemic lupus erythematosus. I. Differences in reactivity with poly (u) and poly-(a) poly (u). J Immunol 1975;115:28-31.

30 Wilusz J, Keene JD: Autoantibodies specific for u1 rna and initiator methionine trna. J Biol Chem 1986;261:5467-5472.

31 Ara J, Ali A, Ali R: Antibodies against free radical modified native DNA recognize b-conformation. Immunol Invest 1992;21:553-563.

-32 Blount S, Griffiths H, Emery P, Lunec J: Reactive oxygen species modify human DNA, eliciting a more discriminating antigen for the diagnosis of systemic lupus erythematosus. Clin Exp Immunol 1990;81:384389.

33 Sano H, Morimoto C: Dna isolated from DNA/anti-DNA antibody immune complexes in systemic lupus erythematosus is rich in guanine-cytosine content. J Immunol 1982;128:1341-1345.

34 Sano H, Takai O, Harata N, Yoshinaga K, Kodama-Kamada I, Sasaki T: Binding properties of human anti-DNA antibodies to cloned human DNA fragments. Scand. J Immunol 1989;30:51-63.

35 Van Helden PD: Potential z-DNA-forming elements in serum DNA from human systemic lupus erythematosus. J Immunol 1985;134:177-179.

-36 Wedderburn LR, McHugh NJ, Chinoy H, Cooper RG, Salway F, Ollier WE, McCann LJ, Varsani H, Dunphy J, North J, Davidson JE, Juvenile Dermatomyositis Research G: HLA class II haplotype and autoantibody associations in children with juvenile dermatomyositis and juvenile dermatomyositis-scleroderma overlap. Rheumatology 2007;46:1786-1791.

-37 Krapf F, Herrmann M, Leitmann W, Kalden JR: Antibody binding of macromolecular DNA and rna in the plasma of sle patients. Clin Exp Immunol 1989;75:336-342.

-38 Hong EE, Okitsu CY, Smith AD, Hsieh CL: Regionally specific and genome-wide analyses conclusively demonstrate the absence of cpg methylation in human mitochondrial DNA. Mol Cell Biol 2013;33:26832690.

39 Collins LV, Hajizadeh S, Holme E, Jonsson IM, Tarkowski A: Endogenously oxidized mitochondrial DNA induces in vivo and in vitro inflammatory responses. J Leukocyte Biol 2004;75:995-1000.

-40 Ytterberg SR, Schnitzer TJ: Serum interferon levels in patients with systemic lupus erythematosus. Arthritis Rheum 1982;25:401-406.

41 Kim T, Kanayama Y, Negoro N, Okamura M, Takeda T, Inoue T: Serum levels of interferons in patients with systemic lupus erythematosus. Clin Exp Immunol 1987;70:562-569.

42 Siegal FP, Kadowaki N, Shodell M, Fitzgerald-Bocarsly PA, Shah K, Ho S, Antonenko S, Liu YJ: The nature of the principal type 1 interferon-producing cells in human blood. Science 1999;284:1835-1837.

-43 Diebold SS, Kaisho T, Hemmi H, Akira S, Reis e Sousa C: Innate antiviral responses by means of tlr7mediated recognition of single-stranded RNA. Science 2004;303:1529-1531.

44 Kerkmann M, Rothenfusser S, Hornung V, Towarowski A, Wagner M, Sarris A, Giese T, Endres S, Hartmann G: Activation with cpg-a and cpg-b oligonucleotides reveals two distinct regulatory pathways of type I IFN synthesis in human plasmacytoid dendritic cells. J Immunol 2003;170:4465-4474.

45 Puig M, Tosh KW, Schramm LM, Grajkowska LT, Kirschman KD, Tami C, Beren J, Rabin RL, Verthelyi D: Tlr9 and tlr7 agonists mediate distinct type i ifn responses in humans and nonhuman primates in vitro and in vivo. J Leukocyte Biol 2012;91:147-158.

46 Ries M, Schuster P, Thomann S, Donhauser N, Vollmer J, Schmidt B: Identification of novel oligonucleotides from mitochondrial DNA that spontaneously induce plasmacytoid dendritic cell activation. J Leukocyte Biol 2013;94:123-135. 